\title{
A STUDY OF PEDESTRIAN PERSONAL SPACE IN A STATION SQUARE
}

\author{
People-to-people avoidance behavior in Nishi-Chiba station square \\ 駅前広場における歩行者のパーソナルスペースに関する研究 \\ 西千葉駅前広場に打ける対人回避行動について
}

\author{
Shouni TANG ${ }^{*}$,Dongyun KWAK ${ }^{* *}$ and Toshio KITAHARA*** \\ タンソウニ, 郭 東 潤, 北原理 雄
}

\begin{abstract}
In a station square, avoidance behavior happens frequently. In order to create a more comfortable and safe walking space, it is necessary to consider people-to-people avoidance behavior and pedestrian personal space. In this research, we analyzed avoidance behavior by pedestrian pathways and discussed pedestrian personal space through the relative positions of two pedestrians in avoidance behavior. The characteristics of pedestrian avoidance behavior and personal space were as follows:

1. Pedestrian avoidance behavior has significant differences between moving in the opposite direction and in the same direction.

2. The distance of avoidance behavior in the morning is the least .

3. Under free walking conditions, the locus of the object's relative position can be considered as the boundary of the subject's personal space.

4. Reduce avoidance behavior: a. Give enough space for pathways of pedestrians. b. Consider the situation of users.
\end{abstract}

Keywords : Personal Space, Avoidance Behavior, Pedestrian, Distance, Station Square パーソナルスペース, 回避行動, 歩行者, 距離, 駅前広場

\section{Introduction \\ 1.1. Background}

As a result of the fast rhythm of urbanism, a large number of people must use a transit station every day. Much attention has been attracted to pedestrian-oriented planning in transport studies, urban planning and $\operatorname{architecture}^{122)}$. If we can design the station square more reasonably and consider people's behavior sufficiently, the square will become a more comfortable walking space.

During the rush hours, pedestrian streams from various directions swarm into the station square. Pedestrian avoidance behavior happens frequently on these crossings. Accordingly, avoidance behavior is a key point in walking space research, and the patterns of pedestrian movement, more specifically how they avoid bumping into each other, must be analyzed.

Tatebe. et al.(1994) had summarized pedestrians' behavior of avoiding obstacles by digital image processing technique. ${ }^{3)}$ However, this research discussed pedestrians' behavior of avoiding people. Takaku. et al.(2008) had counted the distance between two pedestrians of opposite directions and mentioned pedestrian personal space. ${ }^{4)}$ However, the data of the previous research was under experimental conditions. This research counted the distance between two pedestrians under natural conditions. It is different from research under man-made conditions.

In all avoidance behavior processes, the distance between two pedestrians is essential to research pedestrian personal space. Sakuma. et al.(2005) had simulated crowded pedestrians using computers and discussed pedestrian personal space. ${ }^{5)}$ However, the pedestrian personal space was considered to be round in the previous research. Therefore we should analyze the pedestrian personal space extensively through the relative positions of two pedestrians in avoidance behavior.

This research focuses on people-to-people avoidance behavior and pedestrian personal space under natural conditions and attempts to discuss avoidance behavior extensively. The scope of avoidance behavior is a basic evidence for research on pedestrian personal space, defined as how far the pedestrian should keep away from an object to feel safe and comfortable.

\subsection{Purpose}

The main purpose of this research is to clarify characteristics of pedestrian avoidance behavior and personal space on a station square.

\footnotetext{
* Ph. D. Candidate, Graduate School of Engineering, Chiba University (Corresponding Author)

** Assistant Prof., Graduate School of Engineering, Chiba University, Dr. Eng. (Corresponding Author)

*** Prof., Graduate School of Engineering, Chiba University, Dr. Eng.

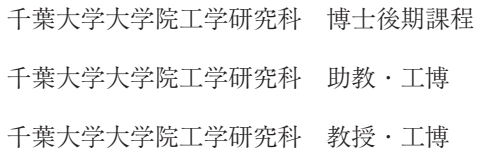


(1) To clarify the differences of avoidance behavior between moving in the opposite direction and the same direction. (2) To clarify the different characteristics of avoidance behavior during different time periods. (3) By depicting the relation between the two pedestrian positions in avoidance behavior, to reveals characteristics of pedestrian personal space on a station square.

\section{Observation}

\subsection{Place}

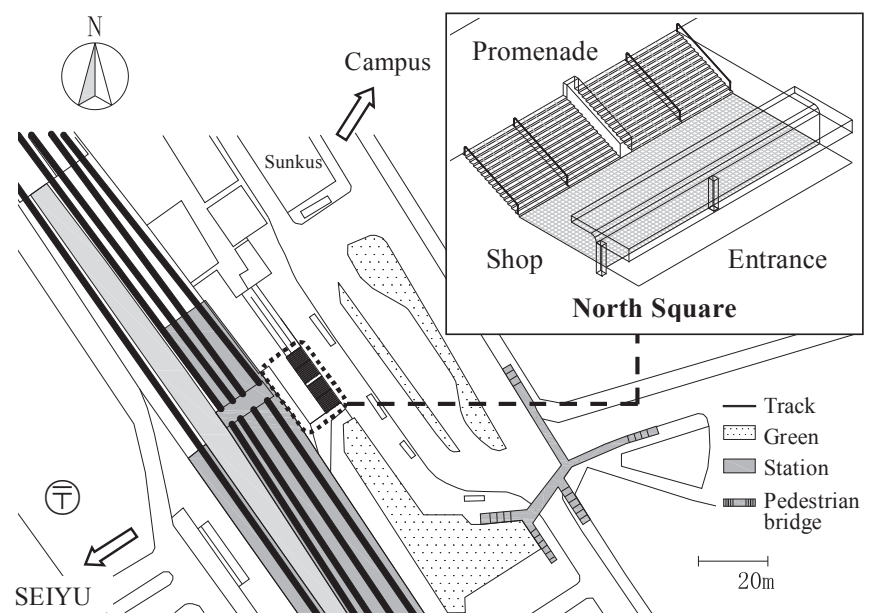

Fig. 1 JR Nishi-Chiba Station, north square

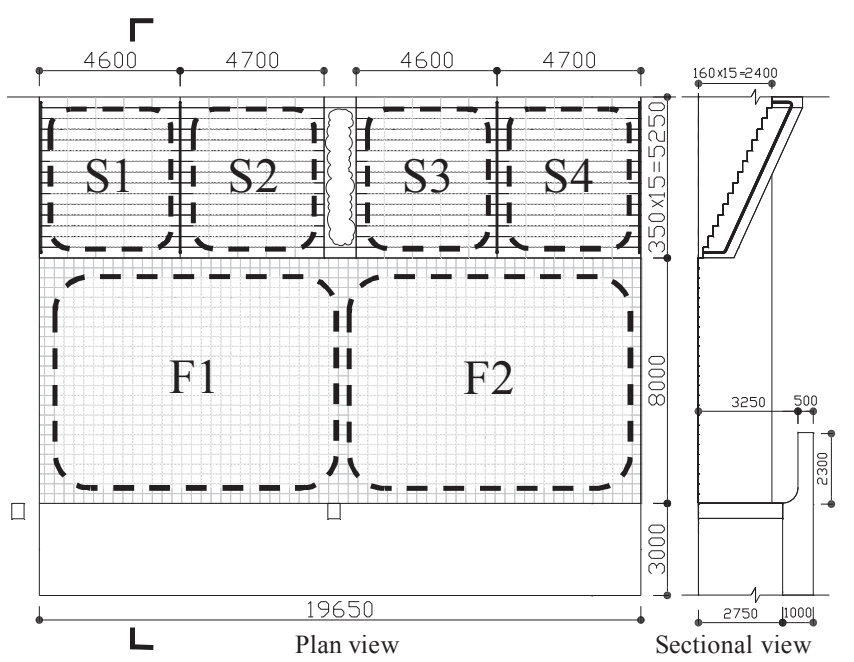

Fig. 2 North square, plan view \& sectional view(mm)

In this research, we took a representative place as an example. According to the previous research ${ }^{6}$, JR Nishi-Chiba Station in Japan is a station which has an enclosed square of the concourse type outside the entrance gate. The primary function of this square is transportation. The crossings of walking pathways happen frequently and the shape of the square is simple and equal. It is suitable for this basic research of avoidance behavior as an object of study, so we took the north square of JR Nishi-Chiba Station as our example(Fig. 1).

We divided the square into 6 zones for this research(Fig. 2): 4 sets of steps and 2 flats. Position: Steps1(S1), Steps2(S2), Steps3(S3), Steps4(S4), Flat1(F1) and Flat2(F2).

\subsection{Observation times}

Nov. 2nd, 2010(Tuesday, Sunny)

We took some videos during these four time periods.

8:00-9:00 rush hour(go to work, go to school)

10:00-11:00 rush hour(go to school)

12:00-13:00 spare hour(lunch)

17:00-18:00 rush hour(go home)

The north of the station square is the university campus. Therefore, there are a large number of people to go to school from the exit of the station to the south gate of the university in the time periods of 8:00-9:00 and 10:00-11:00. The zone of F2 is located near the ticket barriers. Therefore, people tend to pass F2 to the entrance. In the time period of 17:00-18:00, there are a large number of people to go to the entrance of the station for going home.

\subsection{Tool}

$25 \mathrm{~mm}$ wide-angle lens camera and timing device. The camera was placed in a hidden place but we could observe the entire square area.

\subsection{Method}

We took videos for one hour in these time periods. Then we investigated the situation of pedestrian streams and analyzed pedestrian pathways and the scenes of avoidance behavior.

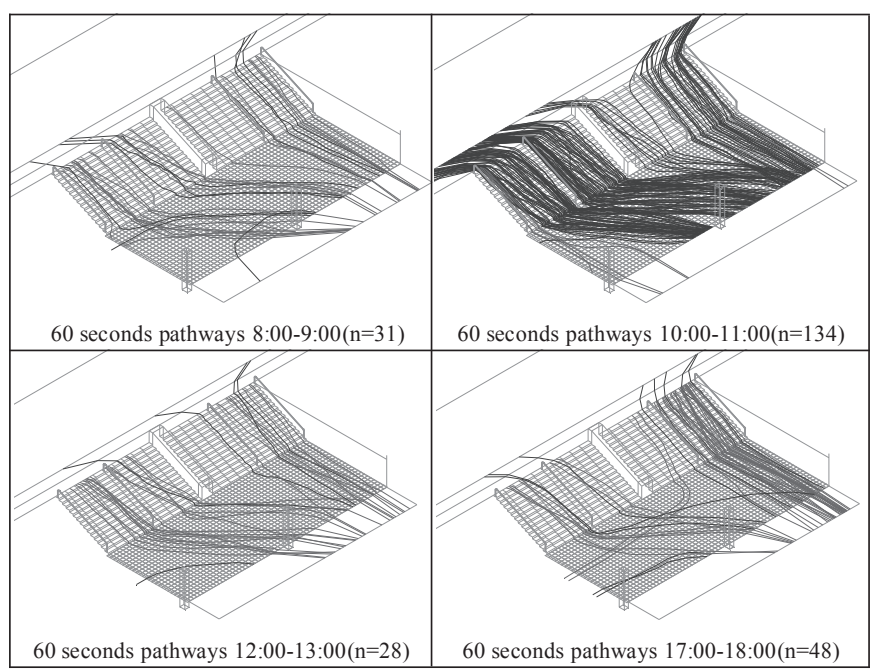

Fig. 3 Pedestrian streams for 60 seconds among every time period

\section{Avoidance behavior and zones}

\subsection{Pathways on the square}

In order to describe situations of pedestrian streams on this square during each time period, we chose lasting 60 seconds of pedestrian streams from every time period video and printed 60 pages of images from these parts of the video second by second. Through these images, we drew the pathways as Fig. 3 .

At the rush hours, the pedestrians just adopted the pathways that they could. At the spare hours, they chose pathways by taking the shortest route. Generally speaking, during these 4 time periods, there are a large number of pedestrians to pass through S4 among 4 zones of steps. More pedestrians pass through F2 than F1(Fig. 3). 


\subsection{Pathways of avoidance behavior}

We randomly selected 30 occasions of people-to-people avoidance behavior from the videos of every time period(8:00-9:00; 10:00-11:00; 12:00-13:00; 17:00-18:00). We then printed some pages of images from each occasion of avoidance behavior. Through these images, we could draw the pathways of the avoidance behavior.

By considering the actual conditions and the methods of previous research $^{3)}$, we determine the positions where avoidance behavior starts on the pathways of avoidance behavior.

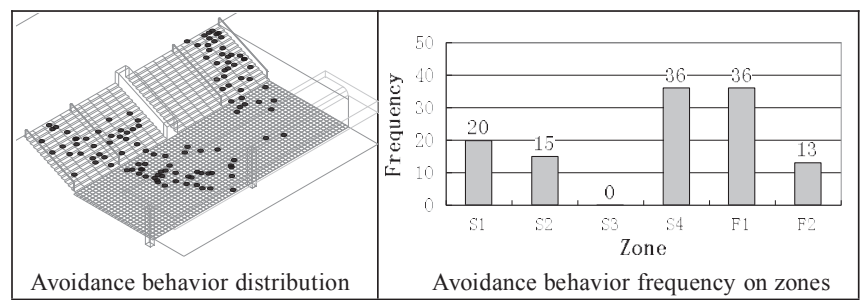

Fig. 4 Distribution of avoidance behavior starting frequency $(n=120)$

\subsection{Frequency of avoidance behavior}

In the position distribution figure of avoidance behavior starting(Fig. 4), we found that frequencies of avoidance behavior in $\mathrm{S} 4$ and F1 are high. The frequency of avoidance behavior in S3 is nearly zero.

There is a relation between the pedestrian streams(Fig. 3) and the frequency of avoidance behavior(Fig. 4). Although, the space of this square is equal, because of shortcut behaviors, the distribution of pedestrian streams is not equal. For taking the shortest route, pedestrians didn't pass through S3, so the frequency of avoidance behavior in S4 increased as the pedestrian streams increased.

The pedestrian streams of F2 are more than F1, but the frequency of avoidance behavior on F1 is observably higher than on F2. The reason is that pathways cross on F1(Fig. 3). These results suggest that avoidance behavior happens frequently in the crossings of pathways.

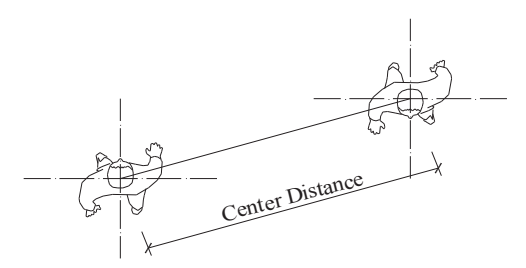

Fig. 5 Center distance

\section{Relation between two pedestrians' positions}

\subsection{Distance of avoidance behavior}

We adopted center distance(Fig. 5) in this research. Center distance is the distance between the centers of balance of two people ${ }^{4)}$. By the pathways of the avoidance behavior, we obtained 3 distances during the process of avoidance behavior: start, nearest and end.

About the decision of the positions of avoidance behavior(start, nearest, end), we considered Tatebe's(1994) methods for judging the starting of avoidance behavior and combined the actual situation of this research to determine the key positions of avoidance behavior. By the pathways and the videos, we could find these key positions when the subjects change their directions or speed. These key positions were constantly at the inflection points of the pathways.

Start: Distance between the subject and the object when the subject starts avoidance behavior.

Nearest: Distance between the subject and the object is the nearest.

End: Distance between the subject and the object when the subject ends avoidance behavior.

\begin{tabular}{|c|c|c|c|c|c|}
\hline Time & $\begin{array}{l}\text { Samples' average } \\
\text { speed }(\mathrm{m} / \mathrm{s})\end{array}$ & Distance & $\mathrm{N}$ & $\operatorname{Mean}(\mathrm{mm})$ & $\begin{array}{c}\text { Std. } \\
\text { Deviation }\end{array}$ \\
\hline \multirow{3}{*}{$\begin{array}{l}\text { 8:00- } \\
\text { 9:00 }\end{array}$} & \multirow{3}{*}{$\begin{array}{l}0.95 \text { (steps) } \\
1.63 \text { (flat) }\end{array}$} & start & 30 & 1021 & 471 \\
\hline & & nearest & 30 & 785 & 230 \\
\hline & & end & 30 & 1113 & 301 \\
\hline \multirow{3}{*}{$\begin{array}{l}10: 00- \\
11: 00\end{array}$} & \multirow{3}{*}{$\begin{array}{l}0.94 \text { (steps) } \\
1.74 \text { (flat) }\end{array}$} & start & 30 & 967 & 437 \\
\hline & & nearest & 30 & 790 & 173 \\
\hline & & end & 30 & 1384 & 614 \\
\hline \multirow{3}{*}{$\begin{array}{l}12: 00- \\
13: 00\end{array}$} & \multirow{3}{*}{$\begin{array}{l}0.89 \text { (steps) } \\
1.60 \text { (flat) }\end{array}$} & start & 30 & 2064 & 583 \\
\hline & & nearest & 30 & 1239 & 344 \\
\hline & & end & 30 & 1719 & 387 \\
\hline \multirow{3}{*}{$\begin{array}{l}17: 00- \\
18: 00\end{array}$} & \multirow{3}{*}{$\begin{array}{l}0.88 \text { (steps) } \\
1.60 \text { (flat) }\end{array}$} & start & 30 & 1468 & 705 \\
\hline & & nearest & 30 & 863 & 216 \\
\hline & & end & 30 & 1320 & 331 \\
\hline
\end{tabular}

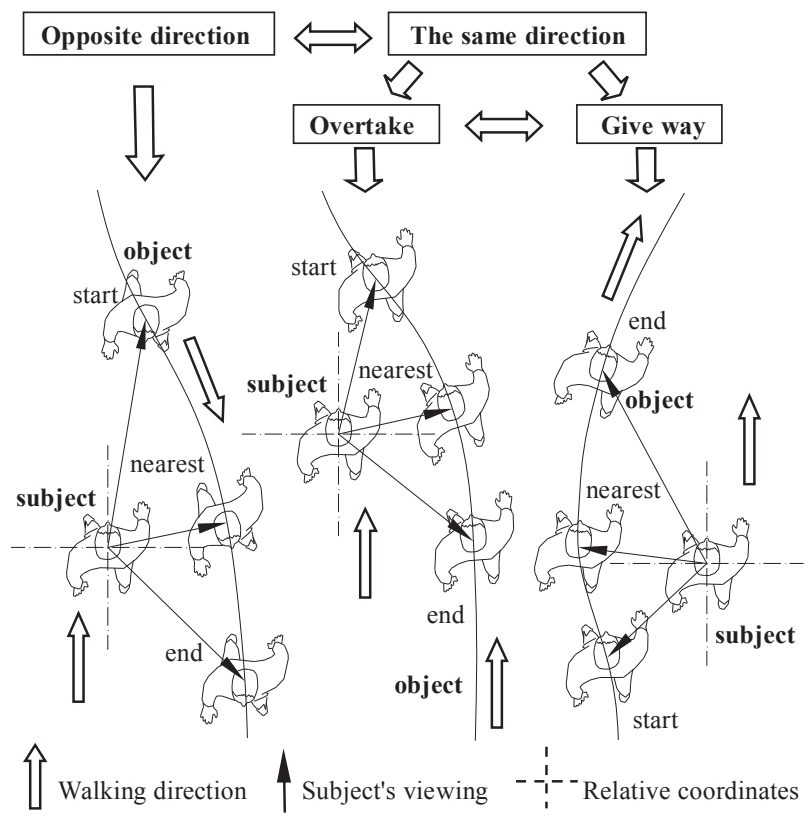

Fig. 6 As subject's viewpoint, avoidance behavior situations

\subsection{Statistics of avoidance behavior distance}

The data of the avoidance behavior distances was subjected to descriptive statistics and statistical analysis as Table 1. These results suggest that the distance of avoidance behavior in the morning is the least among 4 time periods.

\subsection{Avoidance behavior situations}

As shown in Fig. 6, the subject is the person who enact avoidance behavior. The object is the person who is avoided by the subject. 
The aim of this research is to clarify the mind of the subject in avoidance behavior. Therefore, we took the subject's position as the center point of the relative coordinates, where the subject enacts avoidance behavior. From the subject's viewpoint, we could draw the point of the object's position.

If Mr. A and Mr. B both avoid each other, we consider there are two times of avoidance behavior( Mr. A's avoidance behavior and Mr. B's avoidance behavior)

According to the pathways on the station square, the situations of people-to-people avoidance behavior are divided into two types: the two pedestrian directions are opposite; the two pedestrian directions are the same. Going a step further, from the subject's viewpoint, the situations of avoidance behavior in which the two pedestrian directions are the same can be further divided into two types ${ }^{7}$ ): the subject overtakes the object; the subject gives way to the object.

\subsection{Opposite direction and the same direction}

Object's position when subject's avoidance behavior starts

Object's position when subject's avoidance behavior ends

| Object's direction

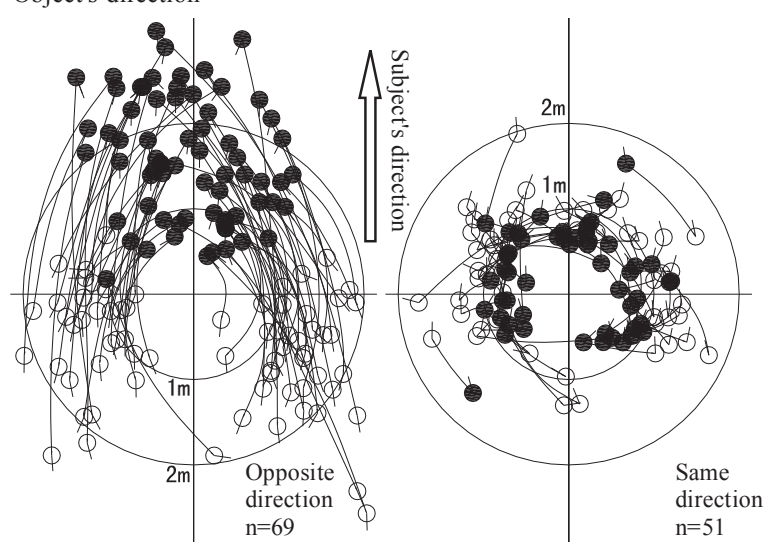

Fig. 7 Distribution of object's positions $(n=120)$

Table 2 Statistics of avoidance behavior distance - opposite \& same

\begin{tabular}{c|ccccc}
\hline Distance & Direction & $\mathrm{N}$ & Mean $(\mathrm{mm})$ & Std. Deviation & T-test \\
\hline \multirow{2}{*}{ start } & opposite & 69 & 1765 & 693 & significant \\
& same & 51 & 858 & 232 & difference \\
\hline \multirow{2}{*}{ nearest } & opposite & 69 & 1012 & 334 & significant \\
& same & 51 & 794 & 220 & difference \\
\hline \multirow{2}{*}{ end } & opposite & 69 & 1523 & 539 & significant \\
& same & 51 & 1195 & 277 & difference \\
\hline \multicolumn{7}{l}{ T-test is at the } & 0.01 level(2-tailed).
\end{tabular}

According to the relation between the two pedestrian positions in avoidance behavior, we can draw the distribution of every object's positions in the same figure. In order to describe the problems clearly, the situations of overtake and give way were combined into the figure of the same direction. We just presented the distribution figures of the opposite direction and the same direction. The central point of the coordinates is the subject's position; the circles are the relative positions of the objects. We use a curve to connect start and end.

The different characteristics of pedestrian avoidance behavior between moving in opposite direction and in the same direction is presented in Fig. 7. The object usually appears in front of the subject and disappears behind both sides of the subject's back in avoidance behavior of the opposite direction. As shown in Table 2, we found that the distance between the two pedestrians becomes greater when the walking directions of the two pedestrians are the same. People go around the object and stop avoidance behavior when they feel safe or comfortable.

After the t-test, the result suggests that the differences of avoidance behavior distance(start, nearest\&end) between moving in the opposite direction and the same direction are significant. The avoidance behavior distance between pedestrians who are moving in the opposite direction is greater than in the same direction(Table 2). During the process of avoidance behavior, the relative displacement between two pedestrians who are moving in the opposite direction is greater than in the same direction(Fig. 7)(Table 3).

Pedestrian avoidance behavior is very different between moving in the opposite direction and the same direction. It means that the subject needs greater distance to avoid the object when two pedestrians are the opposite direction. Therefore, it is necessary to reduce pedestrians' streams of the opposite direction on the station square.

\section{Spaces and distribution of object's position}

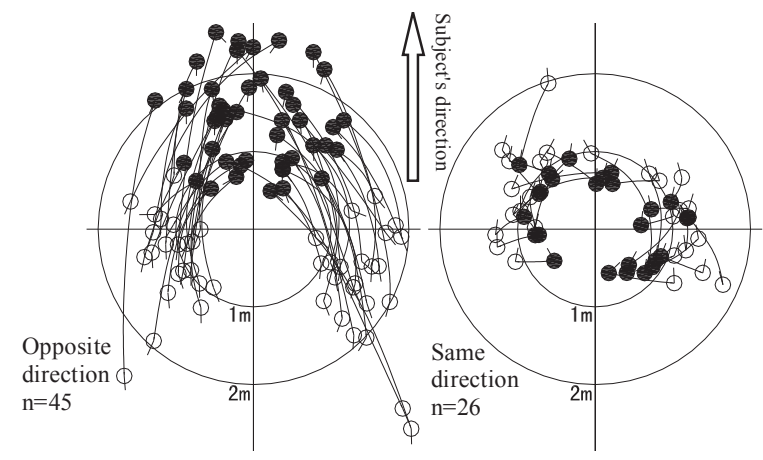

Distribution of object's position on the zones of steps $(\mathrm{n}=71)$

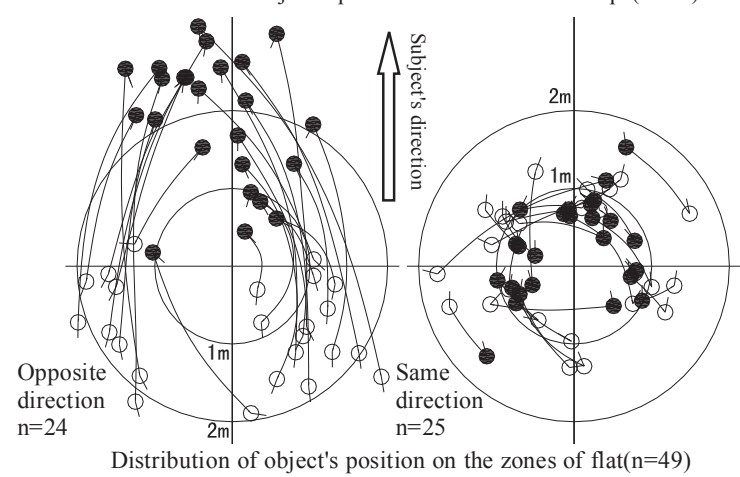

Fig. 8 Distribution of object's position on the steps \& flat $(n=120)$

In order to describe the differences of avoidance behavior between on zones of steps and on zones of flat, we drew the figures of the distribution of object's positions(Fig. 8). The range of avoidance behavior on zones of steps was narrower than on zones of flat. The frequency of avoidance behavior on zones of steps is 71 ; the frequency on zones of flat is 49.(Fig. 4)(Fig. 8) The frequency of 
avoidance behavior on the steps is higher than on the flat. The relative displacement of the object during the process of avoidance behavior is presented in Table 3. The relative displacement of the object on zones of steps was shorter than on zones of flat.

Compared to the zones of flat, the steps is divided by handrails and has height differences. Therefore, these results suggest that the frequency of avoidance behavior increases in the narrow space or on the steps, and the range of avoidance behavior becomes narrower as the space narrows or as the space becomes more complex.

\begin{tabular}{c|ccc}
\multicolumn{5}{c}{ Table 3 Relative displacement of the object } \\
\hline Direction & Zone & $\mathrm{N}$ & Mean $(\mathrm{mm})$ \\
\hline \multirow{2}{*}{ Opposite } & steps & 45 & 2515 \\
& flat & 24 & 2916 \\
\hline \multirow{2}{*}{ Same } & steps & 26 & 877 \\
& flat & 25 & 969 \\
\hline
\end{tabular}

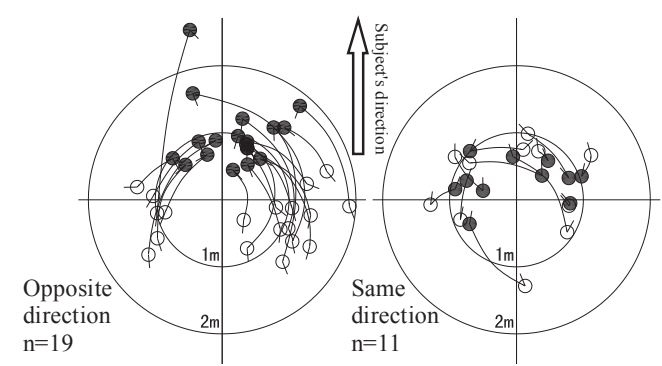

Fig. 9 Distribution of object's position(8:00-9:00)

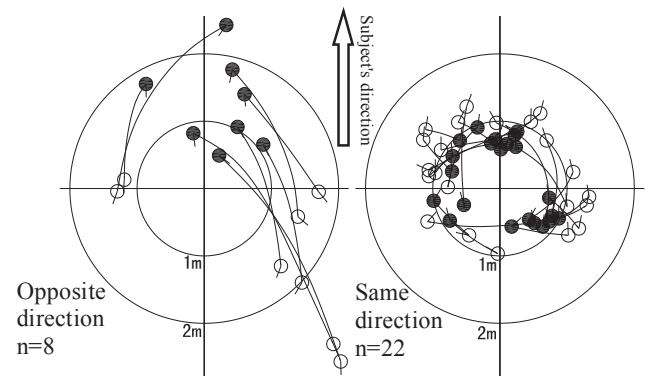

Fig. 10 Distribution of object's position(10:00-11:00)

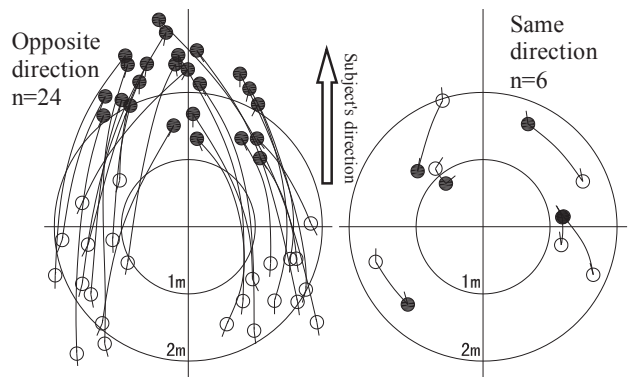

Fig. 11 Distribution of object's position(12:00-13:00)

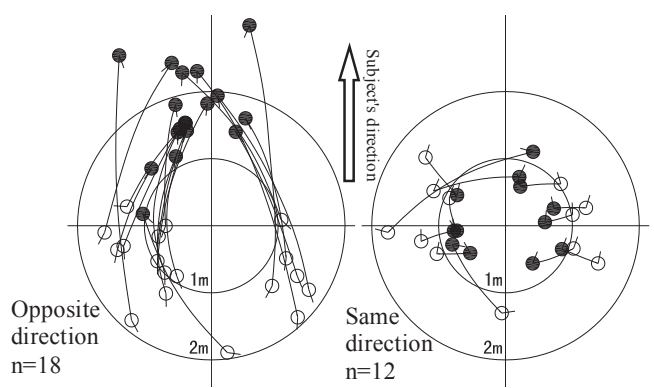

Fig. 12 Distribution of object's position(17:00-18:00)

\section{Time periods and distribution of object's position \\ 6.1. Time period 8:00-9:00}

Fig. 9 shows the distribution of object's positions in the time period of 8:00-9:00. During this time period, there are a large number of pedestrians for going out the entrance and going to the entrance. Therefore, the avoidance behavior of the opposite direction makes up the majority. People are busy going to work or going to school. Their speed is fast. Avoidance behavior distance of the opposite direction is the least. Therefore, the process of avoidance behavior is short. There was a special case where the distance of avoidance behavior was very small, because this subject was a child who nearly ran into the object.

\subsection{Time period 10:00-11:00}

This is a rush hour for going to school determined by class schedule(Fig. 10). During this period, there are a large number of students going to school from the station exit and passing through the square, so that the avoidance behavior of the same direction is the majority. Avoidance behavior distance of the same direction is the least among the 4 time periods.

\subsection{Time period 12:00-13:00}

As shown in Fig. 11, we found that the distances of avoidance behavior(the opposite direction and the same direction) are the greatest among the 4 time periods, because it is a spare hour for lunch, with avoidance behavior of the opposite direction as the majority.

\subsection{Time period 17:00-18:00}

This is a rush hour for going home(Fig. 12) and the density of pedestrians is high, but the distance between the pedestrians is greater than in the morning because pedestrian motivation for fast walking is weaker than in the morning

The distance of avoidance behavior is different during several time periods. Because pedestrians' motivation and pedestrian streams are very different in these time periods. These results suggest that it is necessary to consider the situation of users in station square planning.

\section{Characteristics of avoidance behavior}

\subsection{Walking on the left side}

As shown in Fig. 7, there are 38 times(55.1\%) that subjects pass objects from subjects' left side when their directions are opposite. It suggests that subjects tend toward avoidance behavior on the left side. However, this appearance is not obvious when their directions are the same. Concerning this result, we should note that walking on the left side is a custom in some parts of Japan. ${ }^{* 1)}$

\subsection{Acceleration}

Fifty eight percent of subjects slowed down when they noticed the object and $94 \%$ of subjects speeded up by varying degrees after their avoidance behavior. The pedestrian average speed on the flat and on the steps is presented in Fig. 13. ${ }^{* 2)}$ It seems that pedestrians speed up to compensate for the lost time after avoidance behavior or pedestrians would like to go away from the place of avoidance behavior as soon as possible. 


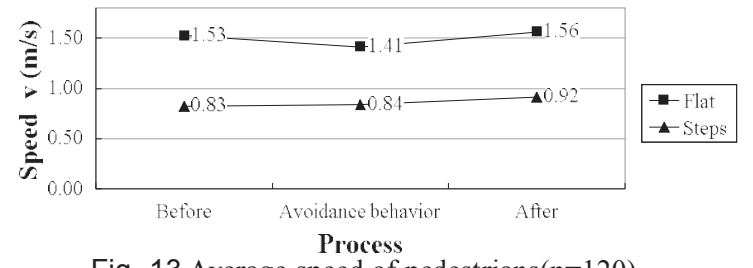

Fig. 13 Average speed of pedestrians $(n=120)$

\subsection{Notice ahead of time}

When avoidance behavior is the opposite direction, the subject on the steps avoids the object on the flat ahead of time. Because the subject is walking at a higher position than the object, he or she notices the object easily.

\subsection{The elderly or the disabled}

Avoidance behavior of the elderly or the disabled lags behind the object, because their reaction speed is slower. As a result, the distance of avoidance behavior starting was less and the distance of avoidance behavior ending was greater than others.

These results suggest that it is necessary to consider pedestrians' behavior custom, feelings, sensory abilities and athletic abilities in station square planning.

\section{Assumptions about pedestrian personal space}

\subsection{Personal space}

Personal space is the area surrounding a person which they regard as psychologically theirs. Most people value their personal space and feel discomfort, anger, or anxiety when their personal space is encroached. The notion of personal space was introduced by Edward T. Hall(1966), who created the concept of proxemics ${ }^{8}$. In his book, The Hidden Dimension, he describes the subjective dimensions that surround each person and the physical distances they try to keep from other people, according to subtle cultural rules ${ }^{* 3)}$.

Table 4 Distribution percentage of objects' positions-start\&end $(n=120)$

\begin{tabular}{ccc}
\hline Percent of Objects & Distance $($ start $)(\mathrm{mm})$ & Distance $($ end $)(\mathrm{mm})$ \\
\hline $10 \%$ & 664 & 889 \\
$20 \%$ & 772 & 1028 \\
$80 \%$ & 2105 & 1721 \\
$90 \%$ & 2541 & 1932 \\
\hline
\end{tabular}

\subsection{Measure of pedestrian buffer area}

We present the distribution of avoidance behavior distance(start \& end) by percentage in order to explain the distribution of the object positions. Table 4 shows that $80 \%$ of pedestrian distance of avoidance behavior starting is shorter than $2105 \mathrm{~mm}$; and that $80 \%$ of pedestrian distance of avoidance behavior ending is greater than $1028 \mathrm{~mm}$.

It seems that the area between $1028 \mathrm{~mm}$ and $2105 \mathrm{~mm}$ is pedestrian buffer area. This area is a part of pedestrian personal space. This measure is used to station square planning.

\subsection{Pedestrian personal space}

We combined the distribution of object points(star and end) for discussing pedestrian personal space(Fig. 14).
Inviolable area: Solid circles(the object's point when the subject's avoidance behavior starts) center out a round area. This area is inviolable area. The inviolable area is the space that others can't get into, no matter which direction the object goes, because it is the closest limit to which people can walk freely.

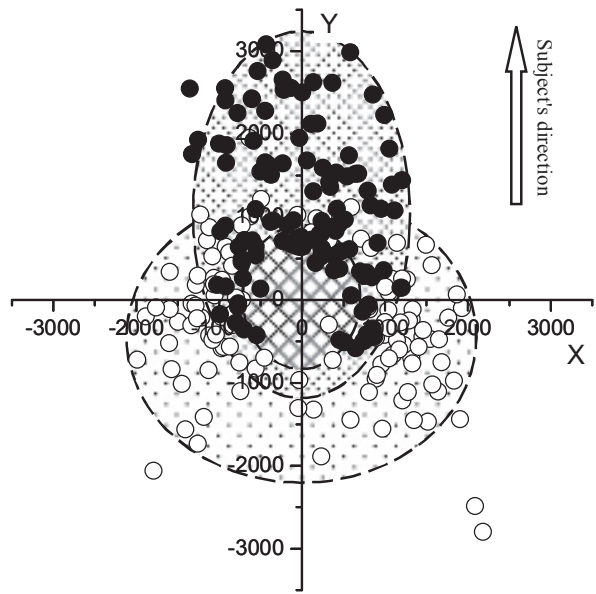

The object's point when the subject's avoidance behavior starts

O The object's point when the subject's avoidance behavior ends

8 Inviolable area $\Leftrightarrow$ Vigilance area $\Leftrightarrow$ Vigilance release area

Fig. 14 Area distribution of personal $\operatorname{space}(n=120)$

Vigilance area: Solid circles(the object's point when the subject's avoidance behavior starts) center in a ellipse area. This area is vigilance area. If the object got into this vigilance area, the subject will make a judgment about enacting avoidance behavior or not according to the object's situation.

Vigilance release area: Hollow circles(the object's point when the subject's avoidance behavior ends) center in a ellipse area. This area is vigilance release area. If the object got into the vigilance release area, the subject will consider this safe and release avoidance behavior.

In Sakuma's research(2005), the pedestrian personal space was considered to be circular. However, the shapes of vigilance area and vigilance release area are not round in this research. It is different from people's personal space under the stationary condition. As the safety of walking is put in the first place ahead of comfort, the shape of vigilance area will be stretched in the axis of the walking direction as the speed increases.

The locus of the object's relative position can be considered as the boundary of pedestrian personal space. In this research, we adopted center distance, so it is necessary to consider people's physical dimensions when the results of this research are used ${ }^{5}$.

\section{Conclusions}

I. Pedestrian avoidance behavior is very different between moving in the opposite direction and the same direction. The distance between two pedestrians who are moving in the opposite direction is greater than moving in the same direction. It is necessary to reduce 
pedestrians' streams of the opposite direction in station square planning.

II. The distance of avoidance behavior in the morning is the shortest among several time periods. Because people have a strong motivation to reach their destinations as soon as possible when they are in a hurry. Especially during morning rush hour, people give up a part of their personal space. The result is that avoidance behavior distance will become shorter and the walking speed will become faster. However, because of the strong territory of people, avoidance behavior distance will become greater in spare hours or at off-duty time.

III. Under freely walking conditions, the locus of the object's relative position can be considered as the boundary of the subject's personal space. $80 \%$ of pedestrian distance of avoidance behavior starting is shorter than $2105 \mathrm{~mm}$. The boundary of pedestrian personal space will be affected by the environment. This measure should be used to station square planning.

IV. Because of shortcut behaviors, the pathways on this square are not equal. Avoidance behavior happens frequently on the crossings of pathways. The range of avoidance behavior becomes narrower as the space narrows and the frequency of avoidance behavior increases as the space becomes more complex. How to reduce avoidance behavior when we design a station square? We should give enough space for pathways of pedestrians in the limited space and reduce crossings of pathways. We should consider the situation of users in different time periods and take into account pedestrians' behavior custom, feelings, sensory abilities and athletic abilities in station square planning.

In the future, the station square is based on characteristics of pedestrian behavior. If the layout of the square is planed to appropriate positions and appropriate scales, pedestrians will move smoothly on heavy station squares.

\section{Notes}

*1) Hideichirou Motohashi. Question of passing from right side, RST Research, vol.23, No.6, 1999, http://www.amy.hi-ho.ne.jp/makj/sub2_3.html

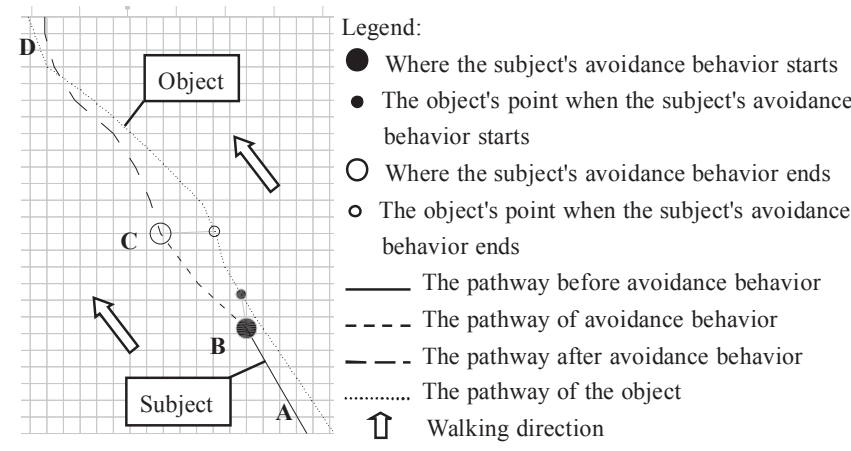

Fig. 15 The pathways of the subject and the object

*2) This is an example for how to calculate the speed of this subject.(Fig.15) Curve A-D is the pathway of the subject through the zones of fiat. Curve $\mathrm{A}-\mathrm{B}\left(l_{\mathrm{AB}}\right)$ is the pathway before avoidance behavior. Curve $\mathrm{B}-\mathrm{C}\left(l_{\mathrm{BC}}\right)$ is the pathway of avoidance behavior. Curve $\mathrm{C}-\mathrm{D}\left(l_{\mathrm{CD}}\right)$ is the pathway after avoidance behavior. By timing device, we could record $t_{\mathrm{AB}}, t_{\mathrm{BC}}$ and $t_{\mathrm{CD}}$ during these 3 periods.
The speed before avoidance behavior: $v_{\text {before }}=\frac{l_{\mathrm{AB}}}{t_{\mathrm{AB}}}$

The speed when the subject enacts avoidance behavior: $v_{\text {enact }}=\frac{l_{\mathrm{BC}}}{t_{\mathrm{BC}}}$

The speed after avoidance behavior: $v_{\text {after }}=\frac{l_{\mathrm{CD}}}{t_{\mathrm{CD}}}$

*3) Interpersonal space refers to the psychological "bubble" that exists psychologically when one person stands too close to another. Research has revealed that there are four different zones of interpersonal space:

1. Intimate distance ranges from touching to about 18 inches $(46 \mathrm{~cm})$ apart, reserve for lovers, children, as well as close family members and friends, and also pet animals.

2. Personal distance begins about an arm's length away; starting around 18 inches $(46 \mathrm{~cm})$ from the person and ending about 4 feet $(122 \mathrm{~cm})$ away. This space is used in conversations with friends, to chat with associates, and in group discussions.

3. Social distance ranges from 4 to 8 feet $(1.2 \mathrm{~m}-2.4 \mathrm{~m})$ away from the person and is reserved for strangers, newly formed groups, and new acquaintances.

4. Public distance includes anything more than 8 feet $(2.4 \mathrm{~m})$ away, and is used for speeches, lectures, and theater. Public distance is essentially that range reserved for larger audiences.(Engleberg, 2006) $)^{9)}$

\section{References}

1) Fruin, J.J.: Pedestrian Planning and Design. Metropolitan Association of Urban Designers and Environmental Planners. New York: NY., 1971

2) Pushkarev, Boris. and Zupan, Jeffrey. M: Urban space for pedestrians: a report of the Regional Plan Association. c1975. Cambridge, Mass: MIT Press, 1975

3) Kenji, Tatebe. et al.: Methods for Judging the Beginning Point of Avoiding Behavior and Avoidance Distance between a Pedestrian and a Standing Obstacle: A Study on Pedestrian Behavior of Avoiding Obstacles. Journal of architecture, planning and environmental engineering, Transactions of AIJ(Architectural Institute of Japan), 465, pp. 95-104, 1994, 11

4) Yosuke, Takaku. and Ryota, Yanase: An Experimental Study about Breadth of Corridor in the Space of Building: the Relationship between Meeting or Avoiding and Impression Evaluation. Hokuriku Chapter, Architectural Institute of Japan, 51, pp. 535-538, 2008, 7

5) Takeshi, Sakuma. et al.: Psychological Model for Animating Crowded Pedestrians. Computer Animation and Virtual Worlds, Vol. 16, No. 3-4, pp. 343-351, 2005

6) Van Ngoc, Ho. et al.: Cluster Analysis of Railway Station and Urban Connection Space: Study on The Relationship of Urban Railway Station Building and Urban Space(part1). Summaries of technical papers of Annual Meeting Architectural Institute of Japan, E-1, pp. 559-560, 2009

7) S, R. Musse and D, Thalmann: A Model of Human Crowd Behavior: Group Inter-Relationship and Collision Detection Analysis. Proc. Workshop of Computer Animation and Simulation of Eurographics' 97, 1997

8) Hall, Edward T.: The Hidden Dimension. Anchor Books, 1966

9) Engleberg, Isa N.: Working in Groups: Communication Principles and Strategies. My Communication Kit Series, pp. 140-141, 2006

\section{和文要約}

駅前広場は回避行動が頻繁に起こる場所である。より快適で安全 な歩行空間を作成するために、対人回避行動及び歩行者のパーソナ ルスペースを考慮する必要がある。この研究は、歩行者の動線によ って回避行動を分析し、回避行動における歩行者の相対的な位置に 基づいて歩行者のパーソナルスペースを検討する。歩行者回避行動 とパーソナルスペースの特性を明らかにした：

1. 歩行者が相手とすれ違う場合は、同一方向の場合より回避行動の 距離が長い。

2. 回避行動の距離は午前中が最短である。

3. 自由歩行の条件の下で、相手の歩行軌跡は歩行者のパーソナルス ペースの境界線とみなすことができる。

4. 回避行動を改善する方法：a. 動線に十分なスペースを提供する。

b. ユーザーの状沉を考慮する。 